\title{
Impact of One Belt, One Road Initiatives on African Infrastructure Development
}

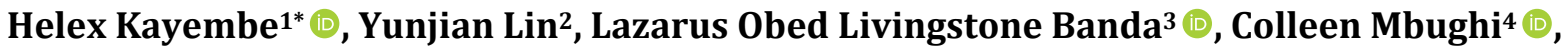 \\ George N. Chidimbah Munthali $\left.{ }^{5}{ }^{(}\right)$, Xuelian $W^{6}{ }^{(1)}$, Jane Thokozani Banda7
}

\author{
${ }^{1}$ Graduate School of Business, Jiangnan University, Wuxi, China \\ ${ }^{2}$ Jiangnan University Alummni Association, Wuxi, China \\ ${ }^{3}$ Graduate School of Education, Beijing Institute of Technology, Beijing, China \\ ${ }^{4}$ Department of Geography, Chancellor College, University of Malawi, Zomba, Malawi \\ ${ }^{5}$ School of Economics and Management, Yangtze University, Jingzhou, China \\ ${ }^{6}$ Yangtze University, Jingzhou, China \\ ${ }^{7}$ Nalikule College of Education, Kanengo Lilongwe, Malawi \\ Email: `helexkayembe@yahoo.com, yunjianl@163.com, chigoba2004@gmail.com, chigoba2004@hotmail.com, \\ colleenmbughi@gmail.com,cmbughi@cc.ac.mw,ndazionaacca@yahoo.com, huaitian07@outlook.com, \\ wuxuelian@yangtzeu.edu.cn, chigonjetsobanda@gmail.com
}

How to cite this paper: Kayembe, H., Lin, Y.J., Banda, L.O.L., Mbughi, C., Munthali, G.N.C., Wu, X.L. and Banda, J.T. (2021) Impact of One Belt, One Road Initiatives on African Infrastructure Development. Open Access Library Journal, 8: e7102. https://doi.org/10.4236/oalib.1107102

Received: December 22, 2020

Accepted: January 25, 2021

Published: January 28, 2021

Copyright $\odot 2021$ by author(s) and Open Access Library Inc.

This work is licensed under the Creative Commons Attribution International License (CC BY 4.0).

http://creativecommons.org/licenses/by/4.0/ (c) $\underset{\mathrm{By}}{\mathrm{By}}$ Open Access

\begin{abstract}
Background: China is one of the developing countries that have witnessed tremendous growth in all sectors of development. One of the strategies that China is using is the reintroduction of the 21st Century Silk Road Economic Belt Development Initiative which moves across the world creating trade partners all around the world. Some of the African countries are among the beneficiaries in this initiative especially in terms of infrastructure development which is ranked behind as compared to other developments. Aim of the Study: This review was aimed at funding out the impacts of OBRI on infrastructure development in African countries. Methods: The data were retrieved from the databases of Scopus, Google Scholars, Web of science with papers that were written in English in the month of September to November 2020. Results: The results of the study indicated that OBRI has positively impacted many participating countries in Africa. However, it is also argued that many African countries over depend on the loans provided through this strategy which acts as a burden. Conclusion: This study recommends that African countries should be underrating clearly the terms of the agreements during the time of signing of the loan agreements by even assessing their capacity to pay back. Besides, African countries should civically educate people on the ownership of these projects for sustainability.
\end{abstract}




\section{Subject Areas}

Business Finance and Investment

\section{Keywords}

Infrastructure Development, BRI/BREI, Silk and Road Initiative, African

Development

\section{Introduction}

Since the onset of its economic reforms and opening up in 1978, China has achieved substantial development resulting in GDP growth averaged almost $10 \%$ annually, and over 850 million citizens have been catapulted out of poverty. These substantial developments have been seen from an agricultural, self-contained, and inward-looking nation into a worldwide economic powerhouse second only to the United States [1]. In line with her rapid economic growth on the international scene, China has tried to operate on the global stage, from Latin America, Middle East, South East Asia, to Africa [2]. One grand global strategy for achieving this is through the implementation of the $21^{\text {st }}$ Century Silk Road Economic Belt Development Initiative, informally known as One Belt, One Road (OBOR) [3]. While some authors have simply abbreviated it as OBR, others call it OBORI. Along the same line, Ngoma [4] contends that the China-Africa relationship has grown exponentially in the past three decades thereby bringing desirable consequences in China being Africa's single largest trading partner, displacing Europe and the United States. China and Africa trade volumes have increased from a paltry USD1 billion in 1980 to USD 200 billion by 2014 [5] [6]. This new partnership has led to many unanswerable questions. Ever since, the Chinese leader conceptualized and developed this giant global economic development initiative at Nazarbayev University in Kazakhstan on $7^{\text {th }}$ September 2013 and thereafter announced before Parliament of Indonesia the New Maritime Silk Road on $3^{\text {rd }}$ October 2013 during a state visit [7] [8]. The topic has been at the centre of numerous global debates among scholars, academicians and policy analysts in the field of International Relations, Business Management, and Politics. Global analysts cantered on either positive or negative impacts of this ambitious and colossal project remain unclear of concrete understanding of the real meaning of the One Belt One Road Initiative (OBORI) and what purposes China is pursuing through it [8].

Some scholars have questioned whether the real meaning of the initiative is grounded in the desire to stimulate economic growth for both China and its partners along the Belt and Maritime Road. Others have been interested in knowing the benefits of the initiative and the possible challenges to its implementation. With keen interest, some scholars have even wondered whether China wants to position itself strategically to easily access and monopolize energy resources and the markets for its continued economic growth. Besides, 
some western countries such as the US, UK, Canada, and also Russia have been interested in knowing what has motivated China to conceptualize this initiative.

This review was aimed at thoroughly scrutinizing the impact of the OBORI strategic framework on African infrastructure, economic, and trade development. Besides, it attempted to find answers from scholars, academicians, political analysts, and other experts such as environmental health specialists about the extent of African's participation in China's global development strategy, its purpose and status in Africa, trade relations, core projects benefits, challenges facing its implementation and recommended solutions for successful implementation of the initiative. To achieve this, this study was directed to answer these research questions;

1) What are the identifiable projects attributed to OBORI in Africa?

2) What are the challenges faced with OBORI implementation?

3) What are the challenges associated with the OBORI projects towards the participating countries?

4) What is the effectiveness of the OBORI in Africa infrastructure development?

\section{Theoretical Framework}

\subsection{Dependent Variable}

This review conceptualized Africa Infrastructure Development (AID) as a dependent variable. Infrastructure is defined as a man-made intervention in the natural setting of physical elements such as roads, bridges, electricity, telephone equipment, water system, and ports together with the creation of linkages among them to promote development [9]. Types of infrastructure include transport, water facilities, and sanitation, energy, and ICT [10]. This review, however, focused on one type of infrastructural development in Africa, the transport infrastructure, which includes airports, ports, rail, and roads [10] [11]. Infrastructure development contributes to economic growth, and poverty alleviation in Africa [12]. African infrastructure development faces many challenges. However, to enhance it, investors, government policies, political stability, funding among others, play a vital role [9] [13] [14] [15].

\subsection{Independent Variable}

The review conceptualized OBORI as an independent variable. The researchers focused on how OBORI affects AID as an independent variable. OBORI is a Chinese initiative to connect the world from Asia, Europe, and Africa through two megaprojects: marine and land transportation development. Apparently, the main purpose of OBORI is to construct infrastructure in countries under OBORI including those in Africa [16] [17]. The focus is on how the OBORI operates on bringing AID, which includes direct funding as well as the use of China manpower [16] [18]. Based on the available literature, this review has also identified some key factors from Africa that affects the operation of OBORI and in 
the long run, it indirectly affects, AID, the dependent variable. These factors include the African countries' political stability and public policy among others [9] [13] [14] [15].

\section{Materials and Methods}

\subsection{Study Design}

This literature review paper was conducted in August 2020 by following PRISMA guidelines for conducting systematic literature reviews and other methodologies used by other researchers in conducting literature reviews [19] [20] [21] [22] [23] as shown in Figure 1.

\subsection{Search Strategy and Data Sources}

The study collected data from four databases, namely: Scopus, Google Scholar, Web of Science and Academia. Researchers used the following search strings: "OBOR in Africa", "OBORI in Africa", "BRI in Africa", "Belt and Road project in Africa", "One Belt One Road Initiative(s) in Africa", "Infrastructure in Africa" and "Infrastructure Development in Africa". After this, the search was conducted from years ranging from 2000 to 2020 . The geographical focus was for Africa countries, we further scrutinized the references of the few selected papers to make sure that a significant number of the updated papers in the field were captured.

\subsection{Eligibility Criteria and Article or Study Selection}

After the download of the data all articles were checked for eligibility to be included in the review using the following guidelines: firstly, the articles had to be written in the English language, secondly, the articles should concern BRI/OBOR/OBORI research in Africa especially about infrastructure development, thirdly, the geographic area should be within African countries which are actively involved in OBORI, fourthly, the article was published between 2000 and 2020, and lastly, an article should be of social science in nature with quality.

\subsection{Risk of Bias}

The papers were cross-checked by three independent researchers (Mr. Kayembe, Ass. Prof. Yunjian Linand Ms. Mbughi). Besides, the third pair of other three independent reviewers reviewed their work (Mr. Munthali, Dr. Wu Xuelian and Mr. Banda) any discrepancies were discussed, a conclusion was reached based on the facts of the paper.

\subsection{Data Extraction and Quality Assessment}

Data were extracted on an excel sheet designed specifically for this study by four independent researchers (Mr. Munthali, Dr. Wu Xuelian, Dr. Liu Jin and Mr. Banda) by using pieces of literature from previous studies which captured the following characteristics: author name, year, country, region, study design, type 
of infrastructure development and industry category, challenges associated with the projects and also identifiable effectiveness. Lastly, the quality of the papers was checked by the third reviews (Ms. Mbughi, Ass. Prof. Yunjian Lin and Mr. Kayembe).

\subsection{Data Analysis}

We analysed data in this study by looking at different perspectives OBORI after taking into account the research aim and questions into account.

\section{Results}

\subsection{Studies Included}

After an initial search from the database, a total number of 200 articles were retrieved. After meeting the inclusion criteria only 48 of these were included in the final writing (See Figure 1 and Figure 2).

\subsection{The Initiative: A Glimpse into China's Strategy}

The original, "Silk Road" was an ancient network of trade routes formally established over 2100 years ago during the Han Dynasty (206 BC-24 AD) to promote trade, peace, cooperation, cultural developments, mutual learning, and benefits essential for increasing developments and prosperity among China, Asia, Africa, and Europe, it spanned over $7000 \mathrm{~km}$ [24]. Trung et al. [25] explained that the vision of the "New Silk Road", or "One Belt, One Road" (OBOR) is determined to take a major step in leading the trends in globalization in the 21st Century. There are different views from scholars, academicians, and policy analysts about the rationale behind the launch of this initiative. The internal goals of OBORI appear to be in line with the logic of strategic partnership whose goal is to realize the stimulating benefits of regional economic growth and development.

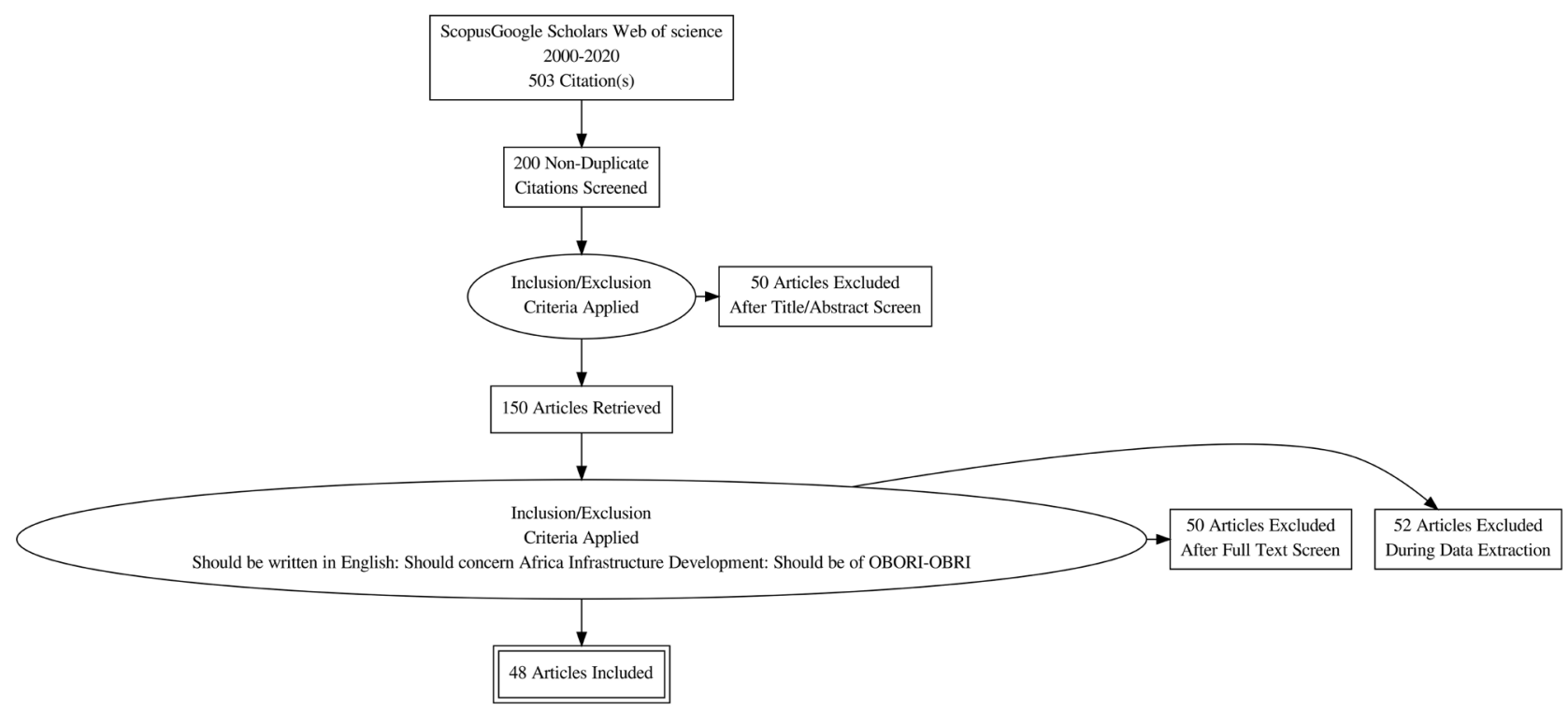

Figure 1. Showing the number of studies included using the PRISMA Method. 


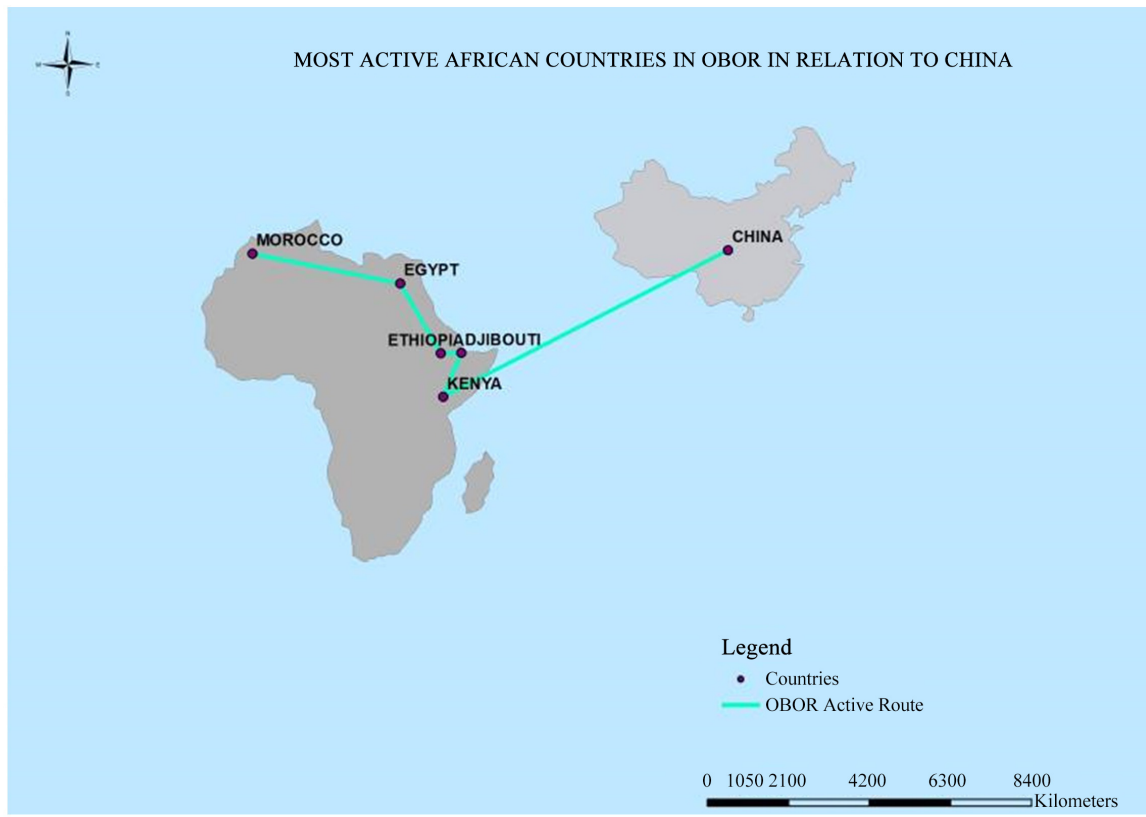

Figure 2. Showing the Map of OBORI route in Africa. Source: Authors work.

\subsection{The Concept of One Belt, One Road}

OBOR initiative is a transformational development strategy and policy framework promoted by Chinese authorities to build a sustained Chinese economic growth and development of economies of its strategic partners along the Belt and Road. This definition is in connection with definitions stated by some scholars who weighed it as a development strategy suggested by China to focus on connectivity and economic cooperation amongst Eurasia, Central Asia and East Africa to stimulate sustained economic growth [26] [27]. OBOR is a good international economic strategy intended at accelerating global economic growth and promoting orderly and free flow allocation of resources and deep integration of markets with China as a leader at the hub of its operationalization of the implementation processes [27]. For the issues of market integration demands and needs full association of other national actors in the global economy, therefore, through the OBOR, China will encourage other nations along the belt and road to achieve economic policy coordination and carry out in-depth regional cooperation initiatives of higher standards [26].

\subsection{Elements of One Belt, One Road, It's Financing and Implementation}

The OBOR development Initiative comprises two important elements in terms of policy agenda, the Silk Road Economic Belt and the 21st century Maritime Silk Road [28]. 1) "New Silk Road Economic Belt" which is expected to connect central and western parts of China to Central Asia, the Middle East up to Western Europe through the Mediterranean Sea by developing road, railway, ICT and energy infrastructures and strengthening economic interdependence and bilateral relations with strategic partners along the Road. 2) The New Maritime Silk 
Road which essentially will connect South China with the South Asia-pacific region, Middle East, African countries (East and South-Eastern and North) through the Indian Ocean and the Red Sea up to Western Europe through the Mediterranean Sea to meet the New silk Economic Road. These two elements are essential and strategic development initiatives that Chinese authorities emphasized would be used by China to integrate itself into the global economy. Many scholars have commented that the initiatives have yielded positive results as, at the time of the review, at least 50 countries had welcomed and supported the strategy.

The positive benefits of OBOR promise to advantage a huge population. Mwatela et al. [3] explained that the development initiative would intend to benefit about 4.4 billion people in 65 nations with a global population of $63 \%$, with a GDP of 2.1 trillion US dollars representing $29 \%$ of the global GDP [29]. The development strategy promises to develop infrastructure along all the routes it cuts through. The Asian Infrastructure Investment Bank (AIIB) (USD 100 million), China Development Bank (CDB) and Export-Import Bank of China $($ Exim Bank $)=>\$ 1$ trillion, China's foreign exchange reserves $=\$ 7$ trillion, China's sovereign wealth fund $=\$ 220$ billion and the silk road fund with a funding portfolio of USD 40 billion has been established to bankroll all projects under the initiative [1] [30] [31]. From these statistics, one would be justified to expect that the initiative will be beneficial to the countries it is targeting.

Realizing the logic of economic interdependence, China appears to have developed OBORI to connect the supply side of production with the demand side. It looks to have realized that it has to be connected to the markets and sources of raw materials for it to sustain its growth. This initiative, therefore, is seemingly connected to the need to distribute wealth and stimulate global economic development.

\subsection{Purpose behind OBORI}

Gimba [32] viewed OBORI's purposes as; 1) Promotion of policy coordination: Focus on promoting regional cooperation to have a common communication system, share interests, and have mutual political trust. 2) Facilitating linkages: OBOR is dignified at making an efficient infrastructure to link entire Asia, Europe, and Africa in stipulated steps. 3) Unimpeded trade: Focus on the promotion and improvement of trade correlated issues and integrating the trade areas' expansion, collaboration as well as the development of modem service trade. 4) Financial integration: Emphasizes the significance of financial support which is subject to using a stable currency system. This has resulted in the development of the Asian Infrastructure Investment Bank (AIIB), China Development Bank (CDB) and Exim Bank, China's foreign exchange reserves, China's sovereign wealth fund, and the Silk Road fund that will strengthen the financial cooperation between its members and partners. 5) People-to-people bonds: Include the provision of support that will be useful in the implementation of the project. Friendly projects promote cultural exchange and mutual learning 
among many people and warrant them to understand, trust, and respect each other and live in harmony, peace, and prosperity.

Some studies have revealed that the main purpose of developing OBORI is to promote and deepen regional economic integration and cooperation opportunities among partners, opening up maritime-based trade corridors, infrastructure development, and coordinated economic production [3] [33] [34]. Also, they found that OBOR aimed at lessening barricades to trade, both literal (for instance, insufficient port, rail, and road infrastructure) and less tangible (for instance, strengthen trade liberalization and easing customs and quarantine processes), encourage a free flow of allocation of resources and deep integration of markets by developing necessary infrastructure supporting market and regional integration. Takyi-Annan et al. [35] contended that OBORI aims at steaming up trade between the People's Republic of China and other countries due to the overproduction of domestic Chinese products resulting from a drop in their population growth rate, hence the need for new markets. On the other hand, others say OBORI aims at conquering world markets by opening up the markets of emerging and developing economies to handle China's excess production capacity, secure supply of natural resources in partner states, promote the internationalization of China's currency, and to make it part of the foreign reserves. Through strengthened diplomatic relationships with partners, China wants to increase her popularity and to build strategic friendships with partner countries and also counter the economic aspects of the U.S.A "strategic-pivot to Asia policy", which include the Trans-Pacific Partnership free trade agreement that seems to discriminate against China.

Various scholars have expressed their views that the aspect of the market and regional incorporation requires joint efforts to open up trade corridors and economic growth, thus it becomes important for global players along the maritime and economic Silk Road to effectively cooperate in the construction of the roads. Leandro et al. [36] was concerned with relationships among partners. He said that OBOR has a diversity of partnerships with various players. But the hierarchical classification of these partnerships is difficult to define due to the interpretation complexities of the Chinese language. Over time, the practice has made China change some of the priorities, practices, policies, and protocols governing the partnerships as witnessed in Cabo Verde. The authors warn that no matter what kind of partnerships exist, there is a great need to cautiously manage and maintain these partnerships and principles governing them.

Even though OBORI has been awarded heightened applause as very important in the contribution towards global social-economic growth and poverty alleviation through trade, overseas-investment, connectivity and other development projects in infrastructure, communication, and technological (ICT) developments there have been different suggestions against its real intention [37]. Some scholars have stated that this is a geopolitical strategy intended at controlling the trade sea routes and at the same time a mechanism through which China wants to dominate and control other players in the international system [38]. With 
respect to SINO-Africa trade relations, some scholars, the media, and western countries think that $\mathrm{OBOR}$ is an initiative to neo-colonize Africa with the one objective of penetrating its markets, secure and access raw materials for running its economic growth engine [3]. On the contrary, other scholars [34] argue that the initiative is an opportunity to unlock regional integration and trade barriers that have been a fundamental bottleneck to global economic growth. Other studies also reported that some African countries view China as having a positive influence in terms of politics and development of the continent [39].

On the part of mutual respect and trust, mutual benefit, win-win cooperation, mutual learning as well as promoting cultural exchange between civilizations, Ascensão et al. [40] observed that there is little evidence that Africa is benefiting on the cultural side as much as China does. They also talked about poor governance and corruption levels in Africa, environmental risks, and challenges along the OBORI route. These include destabilization of regional symbiosis among members of African ecosystems and biodiversity leading to a serious panoply of human health hazards and extinction of treasured flora, fauna, and the so much sought rare earth. Human health will be at stake if the implementation of OBORI doesn't exhort expert advice from environmentalists. Shahriar et al. [41] contended that for a successful implementation of OBOR projects, China needs to extensively involve local communities and take into account all research recommendations from indexed papers. For effective implementation of OBOR in Africa, there is a need for total cooperation, transparency, accountability, and trust between China and Africa to avoid conflict of interest which can hinder the progress of OBOR projects.

\subsection{Benefits of $O B O R$ Initiative}

\subsubsection{OBOR in Africa}

Mwatela et al. and Eshpulat [1] [3] observed that through the 1978 Deng Xiaoping economic reform and opening-up policy, China has intensified its economic transformation technique by way of transforming an agricultural self-contained state into an international economic powerhouse second only to the United States. He stated that for China to achieve this policy it had been very calculative in designing a global economic strategy to share its economic wealth and benefits of growth to the world. Freidberg [2] contends that the Chinese Government has, therefore, executed a global development initiative that intends at developing infrastructures that connect itself to Central Asia, Middle East, Asia-Pacific, Africa, and Western Europe [2]. This has been achieved through (OBOR) Initiative. Key sectors for OBOR include Energy and power; Infrastructure projects; Public utilities; Construction, transport, and logistics; Technology, media, telecoms and information technology, and Financial markets. Many scholars have observed that within this grand development strategy, Africa has been placed at a strategic position as the Maritime Silk Road reaches out to Western Europe through the continental Red sea. The benefit that exists through this strategy is 
focused on infrastructure development, market integration, and regional connectivity. Concurring with other scholars, another researcher, observed that infrastructure development is used as a strategy for establishing bilateral relations with Africa, with most Chinese construction firms generally overlooking environmental standards and labour issues during project execution [42]. A McKinsey \& Company report calculates that over 10,000 Chinese-owned firms operating in Africa, with about $90 \%$ being privately owned. Shrestha [43] found that the OBOR is a vast development initiative to open opportunities to the world especially in Eurasia and in Africa. He added that the significant benefit of OBORI to the world is also regional cooperation. He believed that the OBOR development strategy will change the economic environment in which economies in the region operate, create job opportunities, and enhance people-to-people exchange. Lili, et al. [5] contended that this will impact not only Africa and Eurasian regions but the global economy. The three African countries firstly involved directly in the OBOR development strategy were: Kenya, Djibouti, and Egypt [3] [44]. However, the extent of their involvement is unclear [45] which has attracted many global debates among scholars, academicians, and policy analysts to question possible Chinese hidden intentions for involving these African countries. Many influencing factors have been contributed to the inclusion of these sole three African countries into the centrepiece of China's twenty-first-century diplomacy. Mwatela et al. and Muhammad et al. [3] [45] observed that Djibouti is strategic as it is the entry/exit point of $30 \%$ of world shipping into and out of the red sea. On the security issues, the authors noted that provision of security to sea lanes could help to check and control rising incidences of pirates and terrorism which is rising at an expected rate. Kenya is strategically positioned or targeted because it directly connects the trade routes from the interior of Africa to Mombasa port. The authors noted that China wants to use Kenya to establish the starting project of a land bridge connecting East and West Africa. In all this, trade is key for China, so it needed a country with a port and fully aligned with China. Besides, will enable China to respond rapidly to emergencies in North Africa, the Middle East, and South Asia. Lastly, Egypt is key important because it is at the exit of the Nile and entry into the Mediterranean Sea, very important country for the belt to take off well otherwise it may choke off China program. The authors thought of its strategic geographical location at the Suez Canal which provides it an essential status, explaining why it is the only African nation to officially sign bilateral agreements with China on the OBOR. They noted that the Suez Canal is the transit point between the Indian Ocean and the Mediterranean Sea. Mwatela et al. [3], also noted that it is true out of 67 nations that are in OBOR development initiative; only 3 countries are covered in Africa representing $4 \%$ of the strategy. But the majority of African countries are not officially covered by the initiative and this is challenging considering that most African infrastructures are not yet rehabilitated or constructed. OBOR therefore would provide such an opportunity to construct 
African infrastructure.

\subsubsection{China-Africa Trade Relations}

Winter [46] contended that the rise of the Chinese impact on the African continent from 2000 is confirmed by the expansion in trade, investments, and aid. He added that the Sino-African connections date back to the Han dynasty (206 BC to $220 \mathrm{AD}$ ), pursuing through the Tung, Song, and Ming dynasties. The expansion in trade between China and Africa was confirmed [24] and noted that trade between China and Africa stood at US\$935 million in 1990, and then accelerated to US $\$ 55.5$ billion in 2000 [47] [48]. Other studies reported that from 2001, Africa's exports to China jump up at an annual rate of over $40 \%$ to reach US $\$ 28.8$ billion in 2006, while in the same year (2006) Africa's imports from China quadrupled to US\$26.7 billion [16].

Theodora [42] argued that trade volume between African countries and China has increased. For instance, Theodora noted that the Malawi-China trade volume jumped from $\$ 45$ million in 2008 to $\$ 100$ million in 2012 with more benefits skewed towards Chinese companies. China's Africa Trade amounted to \$10 billion and by 2014 , it had grown to $\$ 220$ billion and is now larger than those of the continent with India, France, and the United States combined. The number of Chinese small-scale business traders doing business in Malawi increased from 900 in the year 2000 to 3500 in the year 2013, with most businesses concentrated in textile, tourism, Agriculture, Buildings, and Mining industries [42]. Much as one may argue that this can create employment for local people but realities reveal that it intentionally or unconsciously suffocates infant local industry to find ways of survival in the competitive trade markets. According to estimates from Thomson Reuters and the World Bank the economic ties between China and the African continent have deepened as China's economy has thrived. China surpassed the United States as Africa's largest trade partner in 2009. China is a destination for $15 \%$ to $16 \%$ of sub-Saharan Africa's exports and the source of $14 \%$ to $21 \%$ of the region's imports [49].

The supply side of Chinese production heavily depends on the import of raw materials which mostly are sourced from African and Middle East Countries. The Economic Outlook Report discloses that China surpassed the United States in Africa in terms of trade and investment in 2008 to become Africa's largest trading partner [14]. For instance, even though African stands around 5\% of China's worldwide trade, trade between China-Africa has grown from US\$1 billion in 1980 and rose to US\$300 billion in 2016 [33]. On the level of African side involvement in OBOR, he reported that it is not clear, and its knowledge is based on Chinese media only. The African ports have been targeted as hubs for transcontinental trade points among Asia, Africa, Europe, and beyond with trade between China and Africa reached a new high of 126.9 billion US dollars in 2010. It also has been recorded that China imports from Africa mainly natural resources like oil (64\%), iron ore and metals (24\%), food and other agricultural products $(5 \%)$, the remaining $7 \%$ is comprised of finished products [8] while Af- 
rica exports only unprocessed raw materials. China represents $1 / 4$ of trade for sub-Saharan Africa (SSA) up from $2.3 \%$ in 1985 , with $1 / 3$ of China's energy imports coming in from SSA [6].

The bilateral trade imbalance between China and Africa has attracted debates among many scholars and political analysts. Literature reports a high trade imbalance between China and Africa, imports from Africa to China declined by up to $40 \%$ while commercial relations shrunk by $18.3 \%$ compared to that in 2014 . This can be attributed to the maturing and slowing down of the Chinese economy in general. However, other researchers argue that also China does most of its trade business with most African countries that are not in OBORI [8]. The China-Africa bilateral trade pattern (import and export) has been steadily growing for the past 16 years. For instance, the research found that the value of China-Africa trade in 2017 was $\$ 155$ billion, while in 2018 was $\$ 185$ billion, an increase of $\$ 30$ billion [37].

We believe that the development of OBOR would enhance trade bonds between Africa and China thereby lowering the trade imbalance which is presently in favour of China. With China involved in all these infrastructural projects in Africa, "coupled with OBOR" vision for enhancing linkages among countries, the initiative will offer a centralized, clear vision, and concerted effort in streamlining AID. Capital for infrastructural development in Africa comes from various Chinese bank loans under individual bilateral agreements entered into by these countries. Through OBOR, the capital inflow can be centrally monitored through the AIIB and the Silk Road Fund (SRF) [3].

\subsection{Core Projects in Africa under the OBOR Development Initiative}

\subsubsection{Kenya}

The Mombasa Port, the building of a new ultra-modern port in Lamu, building a new standard gauge railway line linking Mombasa port in Kenya has symbolized China's presence in Africa [3]. Besides, the authors observed that the $2700 \mathrm{~km}$ railway and the pipe is connecting ports in Kenya, to oil fields in South Sudan and Uganda, while also joining with Ethiopia, Rwanda, Burundi facilitating exports for these countries' products. The projects are being constructed by China Rail and Bridge Corporation and China Communication Construction Company. The projects are funded by China's Exim Bank as a financier amounting to the US $\$ 112$ billion. The completion of the first fully electrified cross-border railway line in Africa, linking Ethiopia's capital, Addis Ababa, to the Red Sea port of Djibouti and Kenya's $845 \mathrm{~km}$ Mombasa to Nairobi railway.

\subsubsection{Egypt}

Mwatela et al. [3] observed that one of the projects under the OBOR development initiative is the expansion of the Suez Canal Economic Zone and the building of new administrative capital for Egypt. The project is being constructed by Chinese industrial developer Tianjin Economic-Technological De- 
velopment Area (TEDA) Investment Co. Ltd. The total cost for expansion of the Suez Canal Economic Zone (SCZone) is estimated at USD 230 million, while for the building of new administrative capital in Egypt is estimated at USD 45 billion. The projects are being funded by Chinese consortium banks. Currently, the project of building a new administrative capital in Egypt has been delayed due to funding while other projects are still in progress.

\subsubsection{Djibouti}

Mwatela et al. [3] observed that the involvement of Djibouti in OBOR is uncertain as Egypt's. However, the authors noted that there are 14 megaprojects in Djibouti total cost will be US $\$ 9.8$ billion. Another project is the construction of a military base at port Dolareh in Djibouti. Both projects are being funded by the Chinese government. The construction of the military base at port Dolareh in Djibouti is estimated at US $\$ 590$ billion, and will mainly be supported by China. The projects have been partly completed.

Although it is officially known that OBOR only strategically targets Djibouti, Kenya, and Egypt in Africa, the Chinese Government has taken initiative to expand OBOR engagement into other Africa countries that are strategically positioned to support the initiative. One such country into which OBOR is expanding is Morocco. Located along the entry into the Mediterranean Sea, this strategic position has motivated China to extend the Belt and Road to this part of Africa. Other projects under OBOR includes the $1780 \mathrm{Km}$ railway line from Tanzania to Zambia, railways have been construction of the railway in Nigeria (1315 $\mathrm{Km}$ ) Kano-Lagos and the $1302 \mathrm{~km}$ Bengue railway line in Angola (which brings to a total $4000 \mathrm{~km}$ railway in Angola constructed by China), $560 \mathrm{~km}$ Belinga-Santa Clara railway in Gabon, $172 \mathrm{~km}$ railway in Libya and $430 \mathrm{~km}$ rail in Mauritania to name but a few. This is a manifestation that OBOR is not geared towards neo-colonization of Africa but rather redistribution of Chinese wealth through win-win initiatives [34].

\section{Discussion}

The primary objective of this review was to find out the impact of OBOR initiatives on African infrastructure development. The review concentrated much on transport infrastructure (including airports, seaports, railways, airways and seaways, and roads). Our review found that transport infrastructure development is used as a tool for establishing bilateral relations with African countries. The review further found that at first only three African countries were covered and benefiting from the initiative, representing $4 \%$ of the OBOR initiative presence in the world. These countries were; Kenya, Djibouti, and Egypt. However, along the way, other African countries have been benefiting from the initiatives. It has also demonstrated that many African nations are not officially covered by the OBOR development initiative and this is challenging considering that most of the infrastructure in such countries is not yet rehabilitated or constructed.

The review suggests that the initiative would provide such an opportunity to 
construct African infrastructure. Even though it appears that all these would benefit directly, the review shows that it is only Egypt that has benefited a lot. However, this is negated by the currently constructed railway from Mombasa to Nairobi and Western Kenya in Kenya. Kenya is targeted because it connects the trade routes directly from the interior of Africa to Mombasa Port. China has got its companies which export raw materials in Uganda, South Sudan, and Sudan to China through Mombasa. While Kenya is benefiting through the railway, it would not be misplaced to propose that the railway was prioritized as it entails win-win benefits for both China and Kenya. The rest of the countries, (Egypt and Djibouti) are geopolitically and strategically situated along the Red Sea and the Suez Canal through which almost 30\% of the world trade shipping passes. One would not question the geostrategic importance that this country has in the whole OBORI. Djibouti is a host to military bases for the US and France, and recently China has just completed its own. This agrees with some literature that suggested that China's OBOR is for geopolitical interests as they might be providing that argument based on the Chinese construction of the base. However, it is in the opinion of the authors that the base is directly connected to provide security to the Africa trade routes which is very often challenged by piracy, extremism, and terrorism.

If well managed, OBOR provides more opportunities for Africa not only in areas of infrastructure development but also in increasing and deepening trade engagements. The review found that the OBOR is seen as the strategy of stimulating economic growth across the world through transport infrastructure development and regional cooperation. This is contrary to the views of some scholars that OBOR is a tool of power dominance by China. For example, China constructed a fully electrified $845 \mathrm{~km}$ cross-border railway line in Africa connecting Djibouti and Kenya's and Tanzania's $(1780 \mathrm{Km})$ railway line from Tanzania to Zambia. Other railways have been constructed in Nigeria Kano-Lagos $(1315 \mathrm{Km})$ and the $1302 \mathrm{~km}$ Bengue railway line in Angola, $560 \mathrm{~km}$ Belinga-Santa Clara railway in Gabon, $172 \mathrm{~km}$ railway in Libya, and $430 \mathrm{~km}$ line in Mauritania. The constructing of Lamu port in Kenya, Bagamoyo in Tanzania, and Mohammed VI tangier Tech city in Northern Morocco. The expansion to other African nations demonstrates that OBOR is not only for Egypt, Djibouti, and Kenya but for the whole continent. This could, therefore, be a chance for Africa to develop its infrastructure. This is a manifestation that OBOR is not entirely geared towards the neo-colonization of Africa but rather a redistribution of Chinese wealth through win-win initiatives [34]. The review also discovered that the seaports and railway lines being constructed are not only assisting China with ease to transport raw materials it imports from Africa and to get the grip of the ever monopolized transport infrastructure by competitors but also that Africa is benefiting from developing and constructing its infrastructure, export products easily and ease transportation challenges it has faced for several years. Of course, the review determined that to achieve this, Africa has to be alert and 
strategically calculative in policy formulation and documentation articulation, lest it may not be a win-win scenario as greatly initiative purport.

Our review has also found that in 2015, there was an acute trade imbalance between China and Africa. For instance, imports from Africa to China declined by up to $40 \%$ while commercial relations shrunk by $18.3 \%$ compared to that in 2014. In terms of China's export to Africa, a review has found that China's exports to Africa were US $\$ 52.86$ billion, an increase of $5.2 \%$ year on year while imports from Africa were US $\$ 49.00$ billion, rising by $0.5 \%$ year on year [47]. This worrisome trend made the authors a bit sceptical about the reality of the touted win-win scenarios. The review has suggested that OBORI would enhance trade bonds between Africa and China thereby lowering the trade imbalance which is presently in favour of China. With China's involvement in all these infrastructural development projects coupled with the vision for improving connectivity among the countries, the strategy may provide a centralized, clear vision, and concerted effort in streamlining infrastructural development in Africa. Capital for infrastructural development in Africa comes from various Chinese bank loans under bilateral agreements entered into by individual countries. This sovereignty of African states jeopardizes the potential of the bargaining power for meaningful agreements. The capital inflow could be centrally monitored through the AIIB and the SRF. The analysis revealed that prevalent trade imbalances may not be an exclusive reflection of the logic of dependency theory but confirmation of the proposition that low levels of technological advancement among Southern African Development Community (SADC) companies. Rather, inadequate skills transfer greatly contributes to the imbalance. OBOR and the funding should provide meaningful opportunities for international and African institutions to work with their Chinese counterparts in the development projects along the routes. Such collaboration could be in the form of joint-ventures or sub-contraction to Chinese corporations looking to implement OBOR projects. Furthermore, Chinese companies could earnestly seek out local partners along the routes to develop projects within host countries. In this way, OBOR would enhance the creation of job opportunities; people-to-people exchange, and transfer of advanced technology to local people. Also, the initiative would promote economic interdependence, regional integration, and maintenance of peace and stability across the regions.

On a negative note, the review found that financing of some projects like the construction of new ports, railways, and pipelines is unclear on how repayments of such high debts to China for some countries like Djibouti and Kenya will be repaid. This may lead such countries to an unprecedented loss of capital assets declared or not yet declared as collateral. Moreover, the review observed that OBORI lacks transparency and accountability to African nations, and the absence of projects that have a direct positive significant impact on the locals have elevated cautious distrust and displeasure. The review suggests that a lack of a clear bilateral agreement will hinder the progress of the OBOR initiative. Our 
review also discovered increasing occurrences of African nations cancelling or postponing OBORI projects over accelerating debt worries. Some governments are too corrupt resulting only in catastrophic misappropriation of some funds meant for national development. On African countries involved in OBOR, the review noted that the opaque nature of various OBOR negotiations hinders public and private sector examination. The review expounded that the absence of appropriate levels of accountability, transparency, and expert knowledge advice, is a recipe for disastrous national poverty levels lower than such countries could get incarcerating debts through OBORI. There are risks of unfavourable consensus and immediately default rise.

The review postulated that OBORI could cause 1) a significant reduction in special flora and fauna which may accelerate the occurrence of related hazardous species and diseases in some Africa countries; 2) logging, poaching, and encroachment would greatly hamper lives and economy of locals. 3) fencing some animals disrupts normal seasonal and habitual migration habits and affects their normal homeostasis, as such they may become disruptive in their behaviour; 4) the intricate crisscross of roads and railways will lead to the extinction of many treasured species of birds and insects through bombarding and crashing into fast-moving vehicles such as cars and bullet trains. This will considerably destabilize the ecosystem. Because of these negative impacts, the resistance of African countries against China's OBORI was noted. This has fuelled local protests against Chinese projects and dozens of incidents of kidnapping and harassment of Chinese workers working on projects across Africa.

Another issue is about monopoly over supply chain which all is done by Chinese from the supply of resources to labour. The review has found that more than 10,000 Chinese-owned firms are operating in Africa, of which $90 \%$ are privately owned. In the same line, in 2015 the total number of Chinese workers working in Chinese infrastructure projects in Africa was 263,659, by the end of 2018 was 201,057, according to official Chinese sources. This hinders the employment of Africans in such projects, as the projects are already full of Chinese workers.

The review exposed that the implementation of OBOR may face challenges of 1) geopolitics if not properly planned in terms of its implementation; 2) increasing levels of piracy, extremism, and terrorism along the Maritime Silk Road; 3) regular deliberately incited yet preventable conflicts and wars in Africa's state; 4) OBOR appears selective in its implementation; 5) high levels of corruption and fraud and mediocre governance among the concerned African countries.

\section{Recommendations}

Because transport infrastructure is very important, Africa is behind in infrastructure development, and one of the main funding partners which is OBOR has some challenges and adverse impacts on the continent all-round stability, the authors of this review make the following recommendations: 1) Despite all 
the challenges and setbacks that Africa is facing on infrastructure development, African countries need to develop their infrastructure sector. In this $21^{\text {st }}$ century, Africa needs to fill the gaps in infrastructure development irrespective of the source of funding. African countries can achieve this by: a) practicing good governance which will promote accountability, reduce corruption and therefore minimize wastage of resources and ensure political and economic stability and reduce the level of risk associated with large and uncouth infrastructural investments. b) Prioritize investment in infrastructure development specifically, the transportation sector, whenever they get funding for the development of infrastructure. There is a need to avoid diverting the resources to other competing investment sectors. c) African countries should focus on the opportunities they have in their countries as well as the continent for infrastructure development before they start engaging in taking loans, these opportunities include trade within the continent, heterogeneous natural resources as well as population growth which have a wider range of the productive age group of people among others. d) African countries should work on developing the human resources since it already has a huge population of productive people, equipping them with infrastructure development skills such as engineering among others could boost infrastructure, rather than depending on foreign expertise. e) They should devise strategies that help them compete to attract talent and quality from the global market to avoid being perpetual donors of top brass human resources to the developed countries, through brain drain, brain circulation, and labour migration. f) For the sustainability of the infrastructure already in place, African countries should civically educate people to have a sense of ownership for the infrastructure items to avoid vandalism which deters development. 2) To fully benefit from the foreign funding partners and investors including OBOR while mitigating their negative impacts, African countries should: a) Take loans that they can manage to pay to avoid falling on a "debt-trap diplomacy". b) Involve expertise in environmental impact assessment before starting the projects to avoid environmental damages. c) Governments should avoid falling into any trap that is attached to funding packages by involving expert economic and legal advice. d) Take more time scrutinizing the terms and conditions attached to the funding to understand it before accepting the funds. This helps collaborating partners to stick to a specific meaning of policy documents governing OBOR partnerships e) African countries should make sure that any partnership in infrastructure development should involve its local people, more especially those along the development infrastructure to increase a sense of ownership, trust and related patriotism on one hand, and the entire community far and wide to avoid monopoly over opportunities by foreigners. This should include the transfer of skills; expertise, and technology, creation of for the indigenous people, such strategies can help combat piracy and vandalism faced by foreign investors. f) African regional entities such as SADC should ensure political stability across the continent and establish a good international linkage (both political and economic) 
within themselves which can help them have one voice on bargaining power towards the foreign investors. g) Investors such as China should sincerely advise developing partner countries to stick to agreements and projects, they got the loans for, to avoid the accumulation of loans and mismanagement of funds by the African countries. This will help African countries to use the funds effectively while not falling into the "debt trap".

\section{Conclusion}

The preceding discussion has extensively reviewed the impact of OBOR on AID. It has revealed that apart from transport infrastructure development such as railways, road, and port development, the OBOR has also enhanced the relationship between the Chinese and African countries. This has led to the development of trade, thereby boosting the Chinese economy on one hand, and the development of some sectors of infrastructure in African countries on the other. However, in some circumstances, the OBOR has portrayed some undesirable impacts on the content of Africa such as the countries falling into the "debt trap" and among others. Furthermore, the review has discovered that there are still lots of challenges that China and African countries face while implementing the OBORI in Africa. Therefore, the authors have come up with several recommendations that both Africa and China can utilize to effectively develop in infrastructure sectors, benefit from foreign funding partners and investors including the OBOR initiative as well as for the effective carrying out of OBOR initiative respectively.

\section{Limitation}

The limitations of this study were the exclusion of papers written in Chinese due to the inability of authors to use the language. Most research papers in this language are written by Chinese who are the owners of the OBOR and the papers might have given some insights to the authors on the views Chinese writers have towards OBOR in Africa.

By the time this review was being done, there is a possibility that other latest papers were not yet published yet were published with the same period. This might have led to the exclusion of some relevant literature.

The review also focused only on the impact of OBOR on AID despite having other infrastructure development partners whose work might be supplementing on the OBOR. Therefore, there is a need for further research to understand how OBOR and other partners for infrastructure development work in Africa, their relationship in terms of infrastructure development in Africa, and the impacts their relationships may have on African infrastructure development.

\section{Acknowledgements}

We would like to thank Dr. E. A. Kayembe for the remarks he gave us on the draft work of our paper. 


\section{Funding}

This project did not receive any funding.

\section{Credit Arthur Contributions}

All the authors contributed equally to this project.

\section{Conflicts of Interest}

The authors declare no conflicts of interest regarding the publication of this paper.

\section{References}

[1] Eshpulat, I. (2019) The Influence of the Trade Relationship between China and Uzbekistan under One Belt and One Road. International Journal of Management and Humanities, 3, 6.

[2] Friedberg, A.L. (2005) The Future of U.S.-China Relations Is Conflict Inevitable? International Security, 30, 7-45. https://doi.org/10.1162/016228805775124589

[3] Raphael, Z. and Mwatela, Z.C. (2016) Africa in China's One Belt, One Road'Initiative: A Critical Analysis. IOSR Journal of Humanities and Social Science, 21, 10-21.

[4] Leslie, A.N. (2016) Introduction China-Africa Relations: Political and Economic Engagement and Media Strategies. African Studies Quarterly, 16, 6.

[5] Li, P.Y, Qian, H., Howard, K.W.F. and Wu, J.H. (2015) Building a New and Sustainable "Silk Road Economic Belt". Environmental Earth Sciences, 74, 7267-7270. https://doi.org/10.1007/s12665-015-4739-2

[6] Kabia, A.B., Huang, J.-Z., Xing, Y.Y. and Kargbo, A.A. (2016) An Assessment of Sino-Africa Trade Co-Operation and Its Impact in Africa (A Case of Sub-Sahara African Economies). International Journal of Management Sciences and Business Research, 5, 86-138.

[7] Du, J.L. and Zhang, Y.F. (2018) Does One Belt One Road Strategy Promote Chinese Overseas Direct Investment? China Economic Review, 47, 189-205. https://doi.org/10.1016/j.chieco.2017.05.010

[8] Yu, J. (2018) The Belt and Road Initiative: Domestic Interests, Bureaucratic Politics and the EU-China Relations. Asia Europe Journal, 16, 223-236. https://doi.org/10.1007/s10308-018-0510-0

[9] Palei, T. (2015) Assessing the Impact of Infrastructure on Economic Growth and Global Competitiveness. Procedia Economics and Finance, 23, 168-175. https://doi.org/10.1016/S2212-5671(15)00322-6

[10] Anderies, J.M., Janssen, M.A. and Schlager, E. (2016) Institutions and the Performance of Coupled Infrastructure Systems. International Journal of the Commons, 10 , 495-516. http://doi.org/10.18352/ijc.651

[11] Kunaka, T. (2017) One Belt One Road Initiative: An African Perspective. https://sites.miis.edu/immersivelearning/files/2018/08/one belt one road initiative - an african perspectivepdf.pdf

[12] Lu, H., Marco Hafner, C.R. and Knack, A. (2018) China Belt and Road Initiative: Measuring the Impact of Improving Transport Connectivity on International Trade in the Region-A Proof-of-Concept Study. RAND Corporation, Santa Monica. https://doi.org/10.7249/RR2625 
[13] Collier, P. and Cust, J. (2015) Investing in Africa's Infrastructure: Financing and Policy Options. Annual Review of Resource Economics, 7, 473-493. https://doi.org/10.1146/annurev-resource-100814-124926

[14] Theofilatos, A., Folla, K., Laiou, A., Mavromatis, S. and Yannis, G. (2020) Identifying Infrastructure Risk Factors in Africa. Transportation Research Procedia, 48, 3163-3172. https://doi.org/10.1016/j.trpro.2020.08.167

[15] Jiya, A.N., Sama, M.C. and Ouedraogo, I. (2020) Infrastructure, Trade Openness and Economic Transformation in Common Market for Eastern and Southern Africa Member Countries. Social Sciences \& Humanities Open, 2, 1. https://doi.org/10.2139/ssrn.3578327

[16] Yii, K.-J., Bee, K.Y., Cheam, W.Y., Chong, Y.L. and Lee, C.M. (2018) Is Transportation Infrastructure Important to the One Belt One Road (OBOR) Initiative? Empirical Evidence from the Selected Asian Countries. Sustainability, 10, 4131. https://doi.org/10.3390/su10114131

[17] Mathews, J.A. (2019) China's Long Term Trade and Currency Goals: The Belt \& Road Initiative. The Asia-Pacific Journal, 17, 1-25.

[18] Sarker, M., Hossin, M., Yin, X. and Sarkar, M. (2018) One Belt One Road Initiative of China: Implication for Future of Global Development. Modern Economy, 9, 623-638. https://doi.org/10.4236/me.2018.94040

[19] Chidimbah Munthali, G.N. and Wu, X.L. (2020) The Future of Tobacco Industry Amidst of COVID-19-A Case of Malawi Producing Country. Biomedical Journal of Scientific \& Technical Research, 27, 2. https://doi.org/10.26717/BJSTR.2020.27.004566

[20] Chidimbah Munthali, G.N. and Wu, X.L. (2020) Straw Markertization in China-Trend and Status. Global Journal of Finance and Management, 12, 19-43. https://www.ripublication.com/gjfm20/gjfmv12n1 02.pdf

[21] Pearson, E.A.A.A. (2014) The Systematic Review: An Overview. American Journal of Nursing, 114, 53-58. https://doi.org/10.1097/01.NAJ.0000444496.24228.2c

[22] Livingstone, O.L.B., Jin, L., Thokozani Banda, J. and Zhou, W.H. (2020) Trending Majors among International Students in China: A Case of African Students? https://ndownloader.figshare.com/files/25551551

[23] Livingstone, O.L.B., Jin, L., Thokozani Banda, J. and Zhou, W.H. (2020) Why Do International Students Underperform in Chinese Universities? A Multi-Theoretical Approach from the Students' Perspective.

https://www.researchgate.net/publication/346059649 Why do international stude nts underperform in Chinese Universities A multi-theoretical approach from $t$ he students' perspective

[24] Li, W. and Hilmola, O.-P. (2019) One Belt and One Road: Literature Analysis. Transport and Telecommunication Journal, 20, 260-268. https://doi.org/10.2478/ttj-2019-0022

[25] Trung, H.Q. and Salatikoye, Y.D. (2019) One Belt One Road a Great Project of Far-Reaching Economic Development and Trend of Global Modern Development Rules. Global Journal of Politics and Law Research, 7, 19-35.

[26] Haggai, K. (2016) One Belt One Road Strategy in China and Economic Development in the Concerning Countries. World Journal of Social Sciences and Humanities, 2, 10-14.

[27] Saleh Shahriar, L.Q., Saqib Irshad, M., Kea, S., Abdullahi, N.M. and Sarkar, A. (2018) Institutions of the 'Belt \& Road' Initiative: A Systematic Literature Review. Journal of Law, Policy and Globalization, 77, 1-13. 
[28] Zhang, Z., He, W.J., An, M., Degefu, D.M., Yuan, L., Shen, J.Q., et al. (2019) Water Security Assessment of China's One Belt and One Road Region. Water, 11, 607. https://doi.org/10.3390/w11030607

[29] Flynt, L. and Wu, B.B. (2016) The New Silk Road and China's Evolving Grand Strategy. The China Journal, 77, 110-132. https://doi.org/10.1086/689684

[30] Yang, Z.Z., He, Y.Z., Zhu, H. and Notteboom, T. (2020) China's Investment in African Ports: Spatial Distribution, Entry Modes and Investor Profile. Research in Transportation Business \& Management, 37, Article ID: 100571.

https://doi.org/10.1016/j.rtbm.2020.100571

[31] Gebauer, S. (2017) China Heads West: “One Belt, One Road "Initiative. The Vision of Xi Jinping's Concept of “One Belt, One Road”. Gdańskie Studia Azji Wschodniej, 11, 51-58. http://dx.doi.org/10.4467/23538724GS.17.003.6864

[32] Gimba, Z. (2018) The Involvement of Africa in the Administration of the One Belt One Road Initiative: An Analysis. International Journal of Research GRANTHAA-LAYAH, 6, 224-233. https://doi.org/10.29121/granthaalayah.v6.i2.2018.1565

[33] Han, X. and Webber, M. (2020) From Chinese Dam Building in Africa to the Belt and Road Initiative: Assembling Infrastructure Projects and Their Linkages. Political Geography, 77, Article ID: 102102. https://doi.org/10.1016/j.polgeo.2019.102102

[34] Ephraim Abel Kayembe, C.Z. (2017) Issue Linkage in the 21st Century Maritime Silk Road: Is It Opportunity to Solve Security Dilemma of Territorial Disputes in South China Sea? American Scientific Research Journal for Engineering, Technology, and Sciences, 30, 260-294.

[35] Georgina Esi Takyi-Annan, Z.M. and Eyram, N. (2018) The One Belt One Road Initiative; Possible Implications on West Africa-Ghana. IOSR Journal of Business and Management, 20, 28-32.

[36] Francisco José, B.S. and Leandro, P.A.B.D. (2019) The Belt and Road Initiative: An Old Archetype of a New Development Model. Palgrave Macmillan, Singapore, 40. https://doi.org/10.1007/978-981-15-2564-3

[37] Githaiga, N.M., et al. (2019) The Belt and Road Initiative: Opportunities and Risks for Africa's Connectivity. China Quarterly of International Strategic Studies, 5, 117-141. https://doi.org/10.1142/S2377740019500064

[38] Godement, F. (2015) “One Belt, One Road”: China's Great Leap Outward. China Analysis. China Analysis.

https://www.google.com/url? sa=t\&rct=j\&q=\&esrc=s\&source=web\&cd=\&cad=rja\& uact $=8 \& v e d=2$ ahUKEwicnaSji6DuAhXPIDQIHeGODcAQFjAAegQIAhAC\&url=ht tps\%3A\%2F\%2Fwww.files.ethz.ch\%2Fisn\%2F191753\%2FChina analysis belt road. pdf\&usg=AOvVaw39Bd bfbzwj1zKrERh-bp0

[39] Chen, J. (2020) Tension and Rivalry: The 'Belt and Road' Initiative, Global Governance, and International Law. The Chinese Journal of Comparative Law, 8, 177-196. https://doi.org/10.1093/cjcl/cxaa009

[40] Ascensão, F., Fahrig, L., Clevenger, A.P., Corlett, R.T., Jaeger, J.A.G., Laurance, W.F., et al. (2018) Environmental Challenges for the Belt and Road Initiative. Nature Sustainability, 1, 206-209. https://doi.org/10.1038/s41893-018-0059-3

[41] Saleh Shahriar, L.Q., Saqib Irshad, M., Sokvibol, K., Abdullahi, N.M. and Sarkar, A. (2018) Institutions of the 'Belt \& Road' Initiative: A Systematic Literature Review. Journal of Law, Policy and Globalization, 77, 13.

[42] Thindwa, T.C. (2015) China-Malawi Relations: An Analysis of Trade Patterns and Development Implications. African East-Asian Affairs, No. 4, 42-77. 
https://doi.org/10.7552/0-4-146

[43] Shrestha, M.B. (2017) Cooperation on Finance between China and Nepal: Belt and Road Initiatives and Investment Opportunities in Nepal. The Journal of Finance and Data Science, 3, 31-37. https://doi.org/10.1016/j.jfds.2017.09.004

[44] Eisenman, J. (2012) China-Africa Trade Patterns: Causes and Consequences. Journal of Contemporary China, 21, 793-810.

https://doi.org/10.1080/10670564.2012.684964

[45] Sabil Farooq, M., Feroze-Master, N. and Yuan, T.K. (2018) An Analysis of China and Africa Relations with Special Focus on "One Belt and One Road". Journal of Law and Judicial System, 1, 25-33.

[46] Winter, T. (2020) Silk Road Diplomacy: Geopolitics and Histories of Connectivity. International Journal of Cultural Policy, 26, 1-15.

[47] Krukowska, M. (2018) China's Economic Expansion in Africa-Selected Aspects. International Business and Global Economy, 37, 84-97.

http://dx.doi.org/10.4467/23539496IB.18.006.9379

[48] Mustafic, A., (2016) China's One Belt, One Road and Energy Security Initiatives: A Plan to Conquer the World? Sarajevo Journal of Social Sciences Inquiry, 2, 107-135. http://dx.doi.org/10.21533/isjss.v2i2.87.g58

[49] Tehmina, S. and Khan, J.Z (2015) Linkages between China and Sub-Saharan Africa. Global Economic Prospects, 2, 9. 